\title{
The Teddy Bear Grab Crane Machine
}

\author{
Rui Zink ${ }^{1}$ \\ [Article copies available for a fee from The Transformative Studies \\ Institute.E-mail address: journal@transformativestudies.org Website: \\ http://www.transformativestudies.org (C2021 by The Transformative
} Studies Institute. All rights reserved.]

\section{YOU WERE NOT THERE}

What do we look for in fiction? If we google something like 'Why do we read fiction' I'm sure we will find dozens of clues, all of them sound enough - or even hundreds. And, likely, thousands of links. I did the experience and, in 0,7 seconds, I got 786000000 results. Historical novels are a different item: why read them? Why would someone consider writing them? Why is theirs such a successful subgenre when, obviously, it should not be?

I always took a concerned approach to the 'historical novel'. Part of me wants to scream, eerily evoking the apoplectic Jack Nicholson in a

\footnotetext{
${ }^{1}$ Rui Zink was born in Lisbon in 1961. He's a professor of Editing and Writing at Universidade Nova de Lisboa, as well as a writer and translator, having published more than 30 books. His work is translated in a dozen languages (including French, German, Hebrew, Italian, Romanian, Serbo-Croatian and Japanese), ranging from fiction to plays, from cartoons to opera. He published his first book in 1986, Hotel Lusitano, hailed 25 years later as one of the best novels of his generation with a celebratory edition. In 1990, Rui Zink was a pioneer of writing courses in Portugal. In 1997, he co-authored, with artist António Jorge Gonçalves, the first graphic Portuguese novel: A Arte Suprema. In 2001, he wrote the first Portuguese online novel, Os Surfistas, with the input of e-readers. He wrote a tetralogy about the crisis, comprising $O$ Destino Turístico (2008), $A$ Instalação do Medo (2012), A Metametamorfose e Outras Fermosas Morfoses (2014) and the short novel $O s s O$ (2015). Aside from being a novelist, he is a playwright, writes comic strips, and frequently creates librettos for operas. As a translator, he has brought into Portuguese, among others, Saul Bellow and Richard Zenith. He was visiting scholar at the University of Massachusetts Dartmouth, reader at the University of Michigan and resident writer at Middlebury College, Vermont, USA. Address correspondence to: Rui Zink, e-mail: zink.rui@gmail.com.
} 